(C) <2021>. This manuscript version is made available under the CC-BY-NC-ND 4.0 license http://creativecommons.org/licenses/by-nc-nd/4.0/

The definitive publisher version is available online at https://doi.org/

10.1016/j.linged.2021.100983 


\title{
Analysing test scripts to improve language materials in the Solomon Islands
}

Marie Quinn

University of Technology Sydney

PO Box 123

Broadway NSW 2007

Australia

(02) 95145439

marie.quinn@uts.edu.au

ORCiD: 0000-0002-1518-2623

\begin{abstract}
This paper reports on a case study from the Solomon Islands where national testing indicates poor performance in English literacy, particularly in the ability to write continuous text. Analysis of a sample of scripts was undertaken based on knowledge from Systemic Functional Linguistics (SFL) to reveal the weaknesses in students' ability to elaborate on events within writing. Teaching and learning materials were subsequently developed using the results of the analysis, drawing on pedagogy associated with SFL. This study illustrates how a principled framework might be used to support the development of both students' and teachers' knowledge of language.
\end{abstract}

Keywords: Solomon Islands; Literacy testing; SFL; pedagogical support 


\section{Introduction: using literacy testing for reform}

Performance in literacy has seen a proliferation of global, regional and national testing regimes in last 30 years, seeking to inform governments and others about progress in largely macro skills, such as reading and writing. Often the purposes of these tests are couched in terms of monitoring and providing quantitative information. The widely used Programme for International Student Assessment [PISA], for example, undertaken by 15 years olds in 76 countries in reading, mathematics and science, purports to help "participating governments to regularly monitor educational outcomes against a common framework" (ACER, 2021b). In Australia, the National Assessment Program, through its main instrument, the National Assessment Program, Literacy \& Numeracy [NAPLAN] for students in Years 3, 5, 7 and 9 echoes this monitoring role by providing "the measure through which governments, education authorities and schools can determine whether or not young Australians are meeting important educational outcomes" (ACARA, 2016). In the setting for this paper, the Solomon Islands, the localised Solomon Islands Standardised Test of Achievement [SISTA] for students in Year 4 and 6 is couched as providing data for policy makers about achievement levels:

An imperative of the SISTA program is that it provides the Minister and his policy makers with valid summaries regarding the health of the system and reliable measures of how well students are achieving the intended curriculum of the Ministry (ACER, 2016, p. 7)

Such testing focusses on the capturing and presenting of data with which to make judgements and comparisons, often in the form of "league tables" and sites such My School in Australia and other Anglophone countries, spaces where schools and school authorities can be assessed and compared based on the results in national testing.

Other tests, however, foreground the pedagogical use of results over merely providing data. As examples, the Progress in International Reading Literacy Study [PIRLS] for Year 4 students worldwide claims to be "designed to inform educational policy and practice by providing an international perspective of teaching and learning in reading literacy" (ACER, 2021a) and the regional Pacific Islands Literacy and Numeracy Assessment [PILNA], used in 15 Pacific nations since 2012 to test literacy at Years 4 and 6, aims to improve student outcomes:

The overall purpose of PILNA is to support the improvement of education outcomes of students in the Pacific Island countries.... [the data] provides a key source of information on student learning outcomes and contexts that could support potential intervention strategies (EQAP, 2019, p. 2, 82).

The challenge, however, for educational authorities and governments is knowing how to use data to identify intervention strategies and improve educational outcomes.

High stakes and widespread testing have been critiqued for many reasons, including the negative effect on particular groups of students (Macqueen et al, 2019) and the pressure placed on teachers to improve results, but without the skills to necessarily understand the 
test and what the results mean (Dreher, 2012). Darling-Hammond (2004) notes that testing only points to the issues, but that improving achievement - and raising standards - requires a look at how the whole system is operating, including the teaching and the setting:

Ultimately, raising standards for students so that they learn what they need to know requires raising standards for the system, so that it provides the kinds of teaching and school settings students need in order to learn. (p. 1082)

This paper is concerned with the second reason for testing, how analysis of test results might inform intervention strategies, particularly in reform and re-organisation of classroom language and literacy materials. It outlines how close analysis applying a Systemic Functional Linguistics [SFL] approach to a sample of student texts from the 2015 SISTA testing identified specific gaps in linguistic and text knowledge of upper primary students as the basis for redesigning English teaching texts, starting in 2017 and currently in production. Presented here is the analysis undertaken on test scripts from Years 4 and 6 and examples of how activities are designed to provide teachers with explicit and visible language teaching. In doing so, the materials seek to raise their teachers' knowledge of language, thus assisting them to teach language more clearly and raise standards across the system.

This case study of analysis and action provides an example of how educational agencies in similar settings might use test data - what is actually produced by students - to take a principled approach to designing intervention strategies.

\section{Language in Solomon Islands and learning English}

Solomon Islands, a Pacific country of 640000 people (SISNO, 2015) living across an archipelago of nearly 700 islands is a multilingual setting, with 73 first languages and further dialects (Simons \& Fennig, 2017). While the creole Pijin is the widely used lingua franca, English is the official language and nominated language of education (Solomon Islands Government, 2016), due to British colonisation prior to independence in 1978. While neighbouring countries, such as Papua New Guinea and Vanuatu, employ a lingua franca for public uses including education, Solomon Islands Pijin has few official uses and the local Ministry of Education and Human Resource Development [MEHRD] maintains a strong English-only policy in publications and oral messaging. However, as found in other settings (e.g. Cincotta-Segi, 2011; Probyn 2006; Quinn, 2013), teachers in Solomon Islands classrooms move between English and a variety of languages to make meaning.

To support learning English in schools, between 1995 and 2005 MEHRD had developed an English language teaching program, Nguzu Nguzu English for Standards (Years) $1-6$. This program currently constitutes the only language resource for many classrooms across the country, and many classrooms may only have one copy for the teacher. The Years $4-6$ program consists of student textbooks organised around themed units about Solomon Islands and the world, some anthologies and teacher guides. The program espouses a "Whole Language" approach to English teaching, articulated in teachers' guides, with an emphasis on immersion and "natural ways" or learning a language, echoing naturalistic 
theories usually reserved for learning a first language (Goodman, 1977; Graves, 1983), popular in Australia in the 1980s. The following advice is given to teachers:

- Children should be exposed to spoken and written English as much as possible (this is sometimes called "immersion")

- Children should learn English in a natural way from their environment, society and culture

- Children should learn English in a meaningful context, such as through a story or activity rather through repetition and meaningless drills

(MEHRD, 1995, p. 3)

What is problematic here is that English is neither "natural" or in the community to be "exposed to spoken and written English", thus there are few opportunities in which to be immersed. The stated reason for learning English - "Confidence in English contributes significantly to the achievement of social, cultural, economic and political potential" (MEHRD, 2005a, 4) - contrasts with the setting in which most aspects of social and cultural life, and even economic and political life, are rendered solely in Pijin and other first languages, providing little opportunity or impetus to use English outside the classroom. Thus, the responsibility tends to lie with the school and textbooks to provide opportunities for learning and using this official language.

The strength of the current teaching materials is that "meaningful contexts" are established for learning English through the inclusion of local issues and history. In Year 5, for example, the unit "Modern Heroes" (MEHRD, 2005b) recounts the life and achievements of an early prime minister, Solomon Mamaloni, and other notables from independence and beyond. However, this meaningful context is not then supported with explicit teaching of English or activities that might build toward representing reflection on the "heroes" through writing. For example, once students have read the recount of the life of Solomon Mamaloni, there is a comprehension activity that touches on the ideas of "hero", the following activity is concerned with the use of much or more in sentences, having no reference to Solomon Mamaloni or heroes. Further, there is no explanation about when to use much or more correctly, leading students to engage in a linguistic guessing game, rather than building knowledge about countables/noncountables in English. Next, a spelling activity presents the following words for learning and inserting into given sentences: arm, take, began, another, nervous, animal, important, popular, famous, basket. Again, these words do not appear in the stimulus text nor build knowledge about modern heroes. The final activity is to construct a recount of a "local hero", offering prompts for content (Make a list of reasons why you think the person you have chosen is a hero, p. 5), but without showing how to use the model text of the ex-prime minister to write about someone in the community. Thus, language learning does not capitalise on the meaningful context built by the initial text or show the ways to build new extended, continuous texts. 
Units of work throughout the textbooks for Years 4-6 present a similar pattern to this example outlined, with rich texts followed by a variety of isolated activities to use English episodically. Even within the isolated activities, little explanation is provided about how to understand and use new language forms. Little opportunity is taken to capitalise on model texts to build extended, culminating texts.

However, it is the ability to produce extended, continuous text that is assessed in the writing component of national SISTA testing at Years 4 and 6 , where students are required to address the given prompt (identical prompt for both levels: to write a recount). Test results have proven to be poor. In 2015, despite the majority of students in both Year 4 and 6 being at or above the standard ( $71.4 \%$ and $58.7 \%$, respectively) in reading, for writing, only $15.2 \%$ of Year 4 students reached the standard, and only 31\% in Year 6 (ACER, 2016), shown in Table 1. These results were similar to those found in 2013 testing (ACER, 2013).

\begin{tabular}{|l|l|l|l|l|}
\hline 2015 & \multicolumn{1}{|c|}{$\begin{array}{c}\text { ABOVE } \\
\text { expected } \\
\text { level }\end{array}$} & $\begin{array}{c}\text { AT } \\
\text { expected } \\
\text { level }\end{array}$ & $\begin{array}{c}\text { EMERGING } \\
\text { AT } \\
\text { expected level }\end{array}$ & $\begin{array}{c}\text { CRITICALLY } \\
\text { BELOW } \\
\text { expected level }\end{array}$ \\
\hline Year 4 & $43.4 \%$ & $28 \%$ & $18.6 \%$ & $11 \%$ \\
\hline SISTA 1 Reading & $7.6 \%$ & $7.6 \%$ & $14.8 \%$ & $70 \%$ \\
\hline SISTA 1 Writing & $35 \%$ & $23.7 \%$ & $14.6 \%$ & $4 \%$ \\
\hline Year 6 & $14.6 \%$ & $16.4 \%$ & $21.6 \%$ & $31 \%$ \\
\hline SISTA 2 Reading &
\end{tabular}

Table 1: Results summary of Year 4 \& 6 SISTA, 2015, Literacy testing (ACER, 2016, p. 12)

The establishment of a Literacy Program Management Unit [LPMU] in 2014 sought to understand and address the issues in language and literacy performance, and between 2014 and 2016 the language teaching program for Years $1-3$ had been comprehensively reformed to build foundational literacy skills. Taking an SFL approach, the reform included identifying a viable model for learning English in a multilingual setting, a program of training for classroom teachers and literacy support officers, and the redevelopment of language teaching resources. The rationale for the focus on SFL as an underlying principle for literacy reform is detailed below.

\section{Choosing a theoretical model}

In seeking to help teachers and students understand how to use English as a language not used in the community, the best choice of a model is one that provides both a way of analysing and understanding how language works as well as a way to talk about and teach language, clearly and explicitly. Based on the work of Michael Halliday (for example, 1968, $1975,1996)$ and developed further by colleagues such as Christie (for example, 2002, 2013), 
Martin (for example, 2009) and Matthiessen (for example, 1995; Matthiessen \& Halliday, 2009), SFL is a meaning-based model of language that articulates various strata of a text: genre (social purpose), discourse, lexicogrammar and graphology/phonology. It has been widely adaption for classroom use, in Australia and other settings (e.g. Christie, 2002; Derewianka, \& Jones, 2016; Macken-Horarik, Love \& Unsworth, 2011; Martin \& Rose, 2005; Schleppegral, 2016) as a way of understanding the texts that students are expected to produce.

As noted by Christie (2013), the analysis of classroom texts in the 1980s led to both an understanding of the sort of texts that children encountered in school and documenting of generic structures, discourse patterns and sentence-level structures of prototypical texts, such as recounts, narratives, explanations, procedures, reports and procedures. SFL then provides a way of understanding the specific discourse and lexicogrammatical choices that realise social goals, for example, how to tell a story, how to instruct a process, how to recount an experience. Halliday identified three metafunctions for language: experiential, textual and interpersonal. Experiential meanings are those that shape the content,

the set of options whereby the speaker encodes his experience of the process of the external world, and of the internal world of his [sic] own consciousness, together with the participants in these processes and their attendant circumstances (Halliday, 1973, p. 134)

The textual metafunction is concerned with how meanings are ordered within the text, for example, what is in the initial position in the clause - the Theme position - that indicates what the writer "assigns prominence in the clause" (Halliday, 1968, p. 212). Halliday (1968) notes that these two metafunctions are closely linked, that they "cannot be entirely isolated from one another in a description of the syntax of the clause" (p. 170) indicating how writers use particular grammatical items to organise the content of the text.

Since Halliday viewed the clause as "organized as an interactive event" (Halliday \& Matthiessen 2013, p. 134), the final metafunction, the interpersonal, is concerned with how meaning in construed between the writer and the reader, how information is offered and received within speech acts and the how evaluative meanings are built through language choices. Halliday contended that "Meaning is intersubjective activity, not subjective" (Halliday 1992, p. 354; emphasis in the original), thus meaning is made between those interacting with the text. Further understanding of interpersonal meanings at discourse level has been enriched by the work of Martin and White (2005) in building an Appraisal framework to account for affect, judgement and appreciation in texts.

To illustrate how SFL metafunctions are used to understand the features of a text, the following explanation refers to Figure 1 which gives an example of a personal recount, the text that is the focus for the SISTA tests in 2015. 
Yesterday all Year 5 went on an excursion to the rainforest at Minnamurra for our project on ecosystems.

When we arrived, we could smell the damp air and we could hear the sound of the lyrebirds.

First, we watched a video about the different plants and animals in the rainforest and how they live together. Then our guide took us to the rainforest and showed us the trees that formed the canopy. There were huge fig trees with massive buttress roots. Some were hundreds of years old and were as wide as the room of a house.

[2 paragraphs omitted here]

We really enjoyed our visit to the rainforest and we learnt a lot about how an ecosystem works.

Figure 1: Personal recount, shortened that given by Derewianka and Jones (2016, p. 127).

A personal recount is widely used in oral forms for everyday encounters to "share experiences and attitudes of all kinds" (Martin \& Rose, 2008, p. 51) and written more formally in school settings. Typically, the generic structure is an orienting statement and then a record of events, organised chronologically. The personal nature of the text is heightened with a comment, providing some appraisal of the whole activity - We really enjoyed our visit - or interspersed throughout the text in response to events.

Although two paragraphs have been removed, each paragraph is organised around the details of each event, moving through the phases of the day. Experientially, the sentences contain process (or verb) choices that are predominantly concerned with activity - arrived, watched, took - and existence (the way things are) - were - all in the past tense. As well as the use of personal pronouns - $I$, we-extended noun groups provide detail of the entities encountered - the sound of the lyrebirds, the trees that formed the canopy, a video about the different plants and animals in the rainforest - and attributes - as wide as the room of a house. Further detail is provided through the use of circumstances, those words or phrases that "illuminate the process [verb] in some way" (Butt et al., 2000, p. 64), by explaining location (to the rainforest, at Minnamurra), time (Yesterday, First) and reason (for our project on ecosystems). Other common circumstances might include manner (e.g. quickly, badly) or accompaniment (e.g. with the rest of the class, along with my teacher).

The chronology of a personal recount is maintained by the textual choices, typically foregrounding circumstances and clauses indicating time in Theme position, seen here in Yesterday, When we arrived, First. Textual coherence is built through the reference chains, such as the recurring use of we to represent Year 5 and use of components of the ecosystem - trees, lyrebirds, canopy, plants and animals - to link the experiences and aim of the day. Interpersonally, the author unfolds the recount as a collection of declarative statements, offered to the reader without invitation to engage further. The author provides some comment on the day (we really enjoyed our visit), but the use of more technical description 
of what they learnt suggests that the author views the experience as a school activity that builds factual information rather than a particularly emotional experience.

This analysis illustrates the opportunities and resources SFL provides for "noticing" particular facets of the language and how language realises particular meanings, a way to "see (and in some cases 're-see') language as fundamentally a tool for thinking with, a meaning-making resource (as opposed to, for example, a set of rules)" (Coffin, 2010, p. 2). In the classroom, SFL proponents have explored the ways in which teachers might use this understanding of how texts work to explicitly articulate knowledge about language, using a "visible pedagogy" (Macken-Horarik, 1998) to recycle language into the creation of new texts. Various classrooms studies have found that building students' explicit language knowledge has improved students' literacy achievement (e.g. Quinn, 2004; Gebhard et al., 2014; Macken-Horarik \& Morgan, 2011). Particularly useful for teaching is working with whole texts to make the connection between reading (seeing language in use) and writing (using language in new ways).

While developed initially in English-dominant contexts, SFL-based strategies have seen further adaptations into teaching English as an additional language [EAL] in a number of contexts (see NALDIC Quarterly Special Issue, 2010; Firkins, Forey \& Sengupta, 2007; Lin, 2016). While cognitive approaches to second language acquisition have worked with ideas of comprehensible input (Krashen, 1985) and output (Swain, 1985), Jones \& Lock (2010) point out that language production is not enough, but rather noticing how language functions within its social - functional - context is vital. In the Solomon Islands setting, English functions in school and other formal contexts so students need to understand how school genres - such as recounts - work and how best to use this language for academic success.

In reviewing and redeveloping the teaching materials for Years $1-3$ in Solomon Islands, SFL principles were used to develop explicit reading and writing teaching strategies, that bring attention to text, sentence and word structures and produce extended texts linked to reading (this work is detailed in Quinn, 2021). To extend the opportunity for "seeing" language into Years $4-6$, the 2015 SISTA tests provided the opportunity to identify both specific strengths and gaps students currently had in writing which led to such poor results. The overall aim of the activity was then to build on these strengths and address the gaps through explicit and contextualised advice to teachers within new textbooks.

\section{Supporting teachers to teach}

Taking a wider international focus, the importance of teachers' professional knowledge in supporting students has been noted (Guerrero et al., 2012; World Bank, 2018), with global reforms aimed at creating "teachers with greater knowledge of the subjects they teach" (Glewwe et al., 2011). While deep knowledge about English will invariably help teachers to support students to learn this "subject", the question arises as how much specialised knowledge teachers need to teach effectively (Macken-Horarik et al., 2011; Love, 2010). In 
resource-poor settings, where teacher training is difficult and expensive, and the target language is not used, the larger question remains: how will this knowledge be built?

One answer to this challenge is to produce teaching materials that support students' learning, but also raise teachers' own knowledge. Harwood (2013) suggests that good teacher guides make the link between research and practice:

Although the area is under-researched, it is clear that innovative guides can develop teachers, expanding their content and pedagogical knowledge through exposure to the latest research findings and ideas for activities that they never previously considered. (p. 27)

Scripting teaching materials and lesson plans in order to direct teaching practice closely has been critiqued as reducing teachers' creativity (e.g. Commeyras, 2007; Dresser, 2012). However, in settings with low teacher training overall and particularly in non-community language - such as Solomon Islands - scripted materials have been found to provide the high support needed to guide teachers into new ways of teaching (Schneider \& Krajcik, 2002). The teacher guides produced for Years $1-3$ are semi-scripted, and teachers had reported in informal discussions that the guides help to know what to do with the texts ${ }^{1}$. Thus, the LMPU staff decided, in consultation with regional educational leaders, that similar support would be provided in Years 4-6, to support teachers to understand better how English works.

A further factor in deciding to focus on making textbooks highly supportive emerged from the responses to a 2016 survey of teachers undertaken by the LPMU in preparation for reforming the textbooks. Teachers indicated that they generally went first to the textbook as lesson preparation, rather than the teachers' notes. Thus, key information about language is located in the textbook for every activity, ensuring both students and teachers have access, and that teachers are provided ways of explaining language clearly and how to use immediately. The teachers' guide provided ways to further enhance lessons and learning.

What follows is the analysis phase of the project, undertaken chiefly by the language consultant (the author), but in collaboration with the local literacy staff in the LPMU. The process provided an opportunity to strengthen language knowledge through the process of co-analysing texts.

\section{Method for analysis phase of the SISTA texts}

\subsection{Study sample}

SISTA is administered as a sample test, in the same manner as other multi-site tests (e.g. PISA). Using sampling validated by ACER (2016, p. 10), the 2015 test was administered to

\footnotetext{
${ }^{1}$ No formal evaluation has taken place of these materials
} 
3322 Year 4 students and 3099 Year 6 students, representing about 20\% of the enrolment at each level ${ }^{2}$.

For this present study, sample of texts from the 2015 SISTA test was selected from the Year 4 (SISTA 1) and Year 6 (SISTA 2) cohort. As there was no systematic archiving of tests, convenience sampling (Lavrakas, 2008) was employed initially to select from what was available, that is, what the literacy team could locate at the MEHRD Assessment office, in boxes labelled "SISTA 2015". Purposive sampling (Silverman, 2001) was then employed to select across available sites, gender and writing success, to provide some representation of the whole cohort of students who sit the test, methodologically to make appropriate inferences of the general population (Arber, 1993). Texts were considered if they contained a discernible recount text. Excluded, for example, was a paper that contained a list of words, but no clause structure, and two papers where students had copied the instructions for writing a recount, supposedly from a classroom poster. Most of the 13 provinces (though not all) were included and a near-equal set of boys' and girls' texts were extracted from the available sites, as well as a range of marker-allocated scores, out of 30 marks. Table 2 provides the numbers of texts derived from this sampling.

\begin{tabular}{|c|c|c|c|c|c|c|c|c|c|c|c|}
\hline & \multirow[b]{2}{*}{$\mathbf{N}$} & \multicolumn{2}{|c|}{ Gender } & \multicolumn{4}{|c|}{ SIST A Scores } & \multicolumn{4}{|c|}{ Scores across genders } \\
\hline & & Boys & Girls & $\begin{array}{l}\text { Top } \\
\text { score }\end{array}$ & $\begin{array}{l}\text { Low } \\
\text { score }\end{array}$ & $\begin{array}{c}\text { Score } \\
>15 / 30 \\
N\end{array}$ & $\begin{array}{c}\text { Score } \\
<15 / 30 \\
N \\
\end{array}$ & $\begin{array}{c}\text { Boys } \\
>15 / 30 \\
N\end{array}$ & $\begin{array}{c}\text { Girls } \\
>15 / 30 \\
N\end{array}$ & $\begin{array}{c}\text { Boys } \\
<15 / 30 \\
N\end{array}$ & $\begin{array}{c}\text { Girls } \\
<15 / 30 \\
N \\
\end{array}$ \\
\hline $\begin{array}{l}\text { Whole } \\
\text { sample }\end{array}$ & 80 & 39 & 41 & & & 28 & 52 & 13 & 15 & 26 & 26 \\
\hline SISTA 1 & 40 & 18 & 22 & $21 / 30$ & $0 / 30$ & 7 & 33 & 3 & 4 & 15 & 18 \\
\hline SISTA 2 & 40 & 21 & 19 & $30 / 30$ & $0 / 30$ & 21 & 19 & 10 & 11 & 11 & 8 \\
\hline
\end{tabular}

Table 2: Sample characteristics

Scoring by local markers used eight criteria (Relevance, Text features, Organisation, Coherence \& structure, Vocabulary, Grammar, Punctuation, Spelling), but it was not clear how these terms were defined. Closer analysis showed that there were many discrepancies between how these were applied to texts. On the whole, longer, neater, well-spelt scripts attracted higher marks, while some very short, messy, badly spelled texts attracted zero, despite having a discernible recount structure, for example. The deviance from the markers' scores ranged from $-/+8$ marks in Year 4 and $-12 /+9$ in Year 6 , indicating sizeable differences. However, applying an SFL lens to the texts produced a similar range of stronger and weaker writing, features of which will be discussed below.

While the reliability of markers - teachers and principals from around the country - is both concerning and interesting to consider further, this paper seeks to explore what students produced as evidence of their linguistic resources rather than critique the marking

\footnotetext{
${ }^{2}$ Based on most current data (2013) available from MEHRD http://www.mehrd.gov.sb/documents
} 
behaviour. Implications for further teacher knowledge-building in order to allot scores more reliably is discussed in the final section of the paper.

\subsection{Analysis parameters}

Each script was anonymised, scanned, coded for gender, location and score (allocated and re-allocated) and then typed verbatim to provide an accurate rendering of the language. To aid analysis of the scripts, some editing accounted for omissions, spelling mistakes and slippages into Pijin. For example, in transcribing the clause so am very happy, the assumed I was added [I] to understand the implied clause participant; in another place bus was changed to bush to account for Pijin pronunciation of the word. Such changes did not change the grammatical functions, but rather assisted in providing plausible rendering of the meanings.

The text task for SISTA 2015 was to write "about something interesting that you did during your last holidays", prompting students to a personal recount, as exemplified earlier in this paper. The texts produced ranged in length from 15 to 283 words, with most texts between 75 and 150 words. Rather than analyse all possible resources within the scope of SFL, the analysis here is concerned with the macro ability to create a purposeful text and the those features that were most salient in terms of the students' use of English, specifically the manner in which they construed their experiences at sentence-level. Thus, the discussion will explore:

- text staging of a personal recount

- experiential function, realised at the lexicogrammar level through the use of participants, process and circumstances

- textual function, realised at the lexicogrammar level through the use of Theme and reference patterns across a text

The interpersonal metafunction was not a focus for this study at the sentence level of the text, but some discussion will be made in regard to the way students use the Comment phase to provide elements of appraisal at a discourse semantic level.

It is noted that within the existing textbooks, recounts had been modelled - for example, the life of Solomon Mamaloni that was discussed earlier in this paper - and included some personal recounts. However, the focus of the activities for writing was on events rather than reflection, thus students had not been taught many of the features that might be expected in the text. In this way, the study reveals what students are able to do with minimal support, and to suggest what might be supported in the future.

The presentation of the scripts uses a framework similar to that employed by SFL analysts (e.g. Eggins, 1994), presenting clauses and constituent labels beneath. Since the sampled texts did not vary greatly in the manner that they set up clauses, it was possible to set up constituent headings in the analysis tables, not usually a feature of this sort of analysis, but 
illustrates the consistent structures used by these writers. Theme choices are indicated with shading and generic structure is indicated in the righthand column.

In discussing the analysis of student scripts, four have been used to exemplify characteristics of lower and higher achieving scripts from each test and are representative of scripts in the sample. Using pseudonyms, the weaker texts are labelled Samuel (Year 4) and Julie (Year 6) while Sera (Year 4) and John (Year 6, in the Appendix) illustrate texts with more complex language.

\section{Analysis findings}

\subsection{Features of weaker writing}

The scripts deemed "weaker" in this study are those with incomplete Recount staging (usually no Comment and/or undeveloped Record of Events) and few elaborated linguistic items, particularly using few circumstances throughout. Such scripts also tend to contain a high amount of repetition. Texts from Samuel and Julie illustrate typical papers from this part of the sample, seen in Tables 3 and 4.

Last one week holiday I went with my brother to the Island. we fishing sea. swim in the sea. we dance in beach. I really enjoy that day on Island.

\begin{tabular}{|c|c|c|c|c|c|c|c|}
\hline & \multicolumn{6}{|c|}{ Clause analysis } & \multirow{2}{*}{$\begin{array}{l}\text { Text } \\
\text { Structure }\end{array}$} \\
\hline & Conj & Time markers & Participants & Processes & & & \\
\hline \multirow[t]{2}{*}{1} & & $\begin{array}{l}\text { Last one week } \\
\text { holiday }\end{array}$ & I & went & with my brother & to the Island. & \multirow[t]{2}{*}{ Orientation } \\
\hline & & Circ: Time & & Action & Circ: $A c c$ & Circ: Place & \\
\hline \multirow{2}{*}{2} & & & we & fishing & [in the] sea & & \multirow{6}{*}{$\begin{array}{l}\text { Record of } \\
\text { events }\end{array}$} \\
\hline & & & & Action & Circ: Place & & \\
\hline \multirow{2}{*}{3} & & & [we] & swim & in the sea & & \\
\hline & & & & Action & Circ: Place & & \\
\hline \multirow{2}{*}{4} & & & we & dance & in beach & & \\
\hline & & & & Action & Circ: Place & & \\
\hline \multirow{2}{*}{5} & & & I & really enjoy & that day & on [the] Island & \multirow{2}{*}{ Comment } \\
\hline & & & & Feeling & Participant & Circ: Place & \\
\hline
\end{tabular}

Table 3: Samuel's text (SISTA 1)

\begin{tabular}{|c|c|c|c|c|c|c|c|}
\hline & \multicolumn{6}{|c|}{ Clause analysis } & \multirow{2}{*}{$\begin{array}{l}\text { Text } \\
\text { Structure }\end{array}$} \\
\hline & Conj & Time markers & Participants & Processes & & & \\
\hline \multirow[t]{2}{*}{1} & & one day & I & went & to the island & $\begin{array}{l}\text { with my } \\
\text { Mother }\end{array}$ & \multirow[t]{2}{*}{ Orientation } \\
\hline & & Circ: Time & & Action & Circ: Place & Circ: Acc & \\
\hline \multirow{2}{*}{2} & & & 1 & collected & some coconut & in the island & \multirow{2}{*}{$\begin{array}{l}\text { Record of } \\
\text { events }\end{array}$} \\
\hline & & & & Action & Participant & Circ: Place & \\
\hline
\end{tabular}




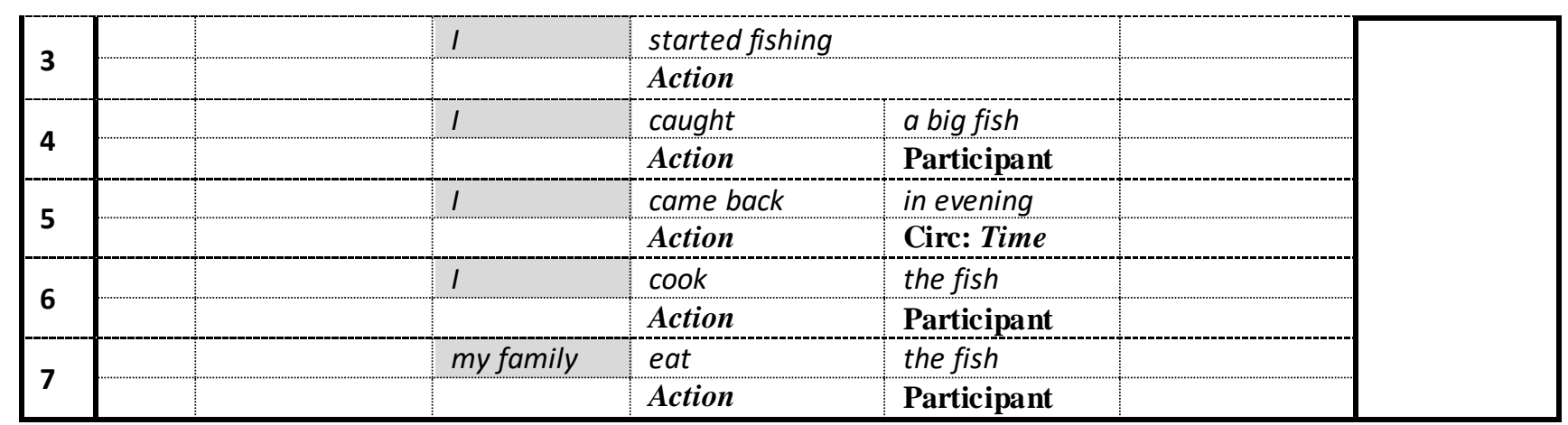

Table 4: Julie's text (SISTA 2)

Both texts constitute recounts since both outline a larger activity - in both cases, going to an island - and are oriented through a time, a place, and accompanying family members. In fact, most recounts in this group similarly establish an overall activity with such elements, with all texts starting with a time circumstance, like these, Last one week holiday and one day. Typical examples include One day at my holiday, Yesterday, Last holidays and During my school holiday. A few students in this group use Once upon a time, presumably as the instructions directed "Write a story (recount)..." leading some students to use a circumstance more congruent with a traditional fairy tale.

Having established the context with an orientation, most texts here, such as Julie's, follow with events linked to the main activity, finishing by simply arriving home and eating fish, or with the discourse signal The end [of] my story. About a third of the recounts in this weaker group, like Samuel, add a comment on the experience in the final sentence, I really enjoy[ed] that day on the island, or occasionally within the text. Examples of this summative comment are we enjoy[ed] our fishing trip and went back home and I was enjoying my school holiday with my friend. Thus, the purpose of a recount is visible across the weaker texts in providing a record of events, some with comment and evaluation that realise more strongly a personal recount.

In terms of events, the verb groups choices construe everyday material processes, or actions, in the life of a village child - went, fish, dance, cook, eat - with few internal processes that would indicate thoughts and feelings, the exception here being when Samuel uses enjoy. In such weaker texts, the processes are largely around the action of going to an island and catching/eating fish, with some playing football and swimming, all congruent with holiday activities and without complexity.

The participants within weaker texts are marked by high repetition of simple noun groups. The participant choice in Samuel's text is predominantly we and $l$, with the addition of the fish in Julie's. There are few modifiers (e.g. adjectives) to provide richer description, and Julie's use of the big fish is the largest noun group shown here. Across other weaker texts, I and we are similarly prevalent and repeated, with short noun groups, often modified with my: my mother, my friend, my brother, my team. Other short noun groups denote the island, the fish, some kumara, the canoe, the holiday, some presents, some fish. Across this group of texts, the longest noun group is the people in my community, but generally there is 
little embedding of information into the descriptions of people, places and things involved in the events.

Circumstantial information is also highly repetitious with few types being used. Most students use a circumstance of time to orient their text, such as Samuel's use of Last one week holiday and Julie's one day, and while Julie uses in the evening further into her text, there are few other references to time are used within recounts to organise the unfolding events. As shown in the earlier reference text, time or order would be expected throughout a recount.

It might also be expected that a recount would be further organised through the use of temporal and ordering conjunctions, such as then or next. However, such conjunctions are not evident in these texts or other texts in this group.

What Samuel and Julie are more concerned about is the placement of activities - to/in/on the island, in the sea, in [the] beach - and who they went with - with my brother, with my mother. Again, these choices are typical across all sample texts with place (in the house, in the sea, to my home, at the store, in the village) being the most common circumstance choice, with instances of accompaniment (with them, with my friend, with me). Most noticeable across these texts is that while the orienting clause has some complexity in useing multiple circumstances (Samuel uses time, accompaniment and place), writers then tend to use recurring and unelaborated clause patterns across the text. For example, Samuel uses a pattern of participant-process-circumstance and Julie uses participantprocess-participant. Thus, the texts are highly repetitious in terms of the order of elements within the clause and the nature of those elements.

Finally, in highlighting the words or phrases in Theme position, the students' choices of clause focal points are revealed. In the case of Samuel and Julie, beyond the orienting clause they thematise themselves and companions, congruent with the personal nature of the text. Students with more focus on the recount aspect included circumstances of time in Theme position, such as On Monday, after[that], every morning, on my last day, but generally, clauses in this group begin with the thematised participant, themselves and their companions.

\subsection{Features of stronger texts}

While the length of a script is not a guarantee of linguistic competency, it is noticeable that scripts longer than 15 clauses tend to include more complexity in the language and more variety of expression. One overriding feature of the stronger and more complex texts is that they tended to report on experiences of travelling beyond their home, to the capital, Honiara, or larger towns such as Auki. Such experiences provided the student writer not only more to diverse activities to write about, but the considerable impact made by the novelty of their experiences provided them with distinctive detail and reactions. Thus, the opportunity to holiday in "exotic" locations presented an advantage in this task, particularly 
over students without the means to travel the distances needed to have such an experience. As an example of the impact of such opportunity, one of the stronger texts came from a boy in Renbel, a remote and tiny island group over an hour's flight from Honiara. This text enthusiastically described a trip to the capital to see his family, with the delightful observation "I played with someone I didn't know. His detailing of the various new experiences indicated the stark difference from life on his island and provided more experiential and interpersonal opportunities to write about. While it is possible to write with depth and detail about the experience of visiting an island and fishing, it was noted that the weaker texts are mainly concerned with these more everyday experiences for village children, less of what would constitute a holiday, and perhaps providing less "interesting" material to recount. Thus, the task itself set up some inequities in simply having "a holiday" to write about.

To illustrate linguistically stronger texts, the initial 11 clauses (of 28) from Sera in Year 4 are analysed in Table 5. In consideration of space, a second text at this level by John in Year 6 is provided in the appendix and will be discussed with Sera's.

In my holidays I went to Honiara with my sister and we aurred to the wolf. my casin sister talk me to the car and she give me my fare and I give to the drava. I like to ging to Kolale area them after three week my mother and my brother came to Honiara too. so am very happy because my mother was come after four week my mothe told me to shopping some drese and sikes for me them my mother said tomoro I went home then I cry for her and my mothe said okey you and me will go home tomoro. on morning I works up we prepare your thing ready we weit for car. sandely the car has come and went insaid and said goodbuy anuty okey buy so she anrrel to the wolf and we went to the ship before the [ship] went out my brother said goodbuy. this is the end of the story.

\begin{tabular}{|c|c|c|c|c|c|c|c|}
\hline & \multicolumn{6}{|c|}{ Clause analysis 1 - 11} & \multirow{2}{*}{$\begin{array}{l}\text { Text } \\
\text { Structure }\end{array}$} \\
\hline & Conj & Time markers & Participants & Processes & & & \\
\hline \multirow[t]{2}{*}{1} & & In my holidays & I & went & to Honiara & $\begin{array}{l}\text { with my } \\
\text { sister }\end{array}$ & \multirow{2}{*}{ Orientation } \\
\hline & & Circ: Time & & Action & Circ: Place & Circ: $A c c$ & \\
\hline \multirow{2}{*}{2} & and & & we & arrived & \multicolumn{2}{|l|}{ to the wharf } & \multirow{8}{*}{$\begin{array}{l}\text { Record of } \\
\text { Events }\end{array}$} \\
\hline & & & & Action & Circ: Place & & \\
\hline \multirow[t]{2}{*}{3} & & & $\begin{array}{l}\text { my cousin } \\
\text { sister }\end{array}$ & took & me & to the car & \\
\hline & & & & Action & Participant & Circ: Place & \\
\hline \multirow{2}{*}{4} & and & & she & give & me & my fare & \\
\hline & & & & Action & Participant & & \\
\hline \multirow{2}{*}{5} & and & & 1 & give & \multicolumn{2}{|l|}{ to the driver } & \\
\hline & & & & Action & Circ: Place & & \\
\hline \multirow{2}{*}{6} & & & 1 & liked going & to Kolale area & & \multirow{2}{*}{ Comment } \\
\hline & & & & & Circ: Place & & \\
\hline \multirow[t]{2}{*}{7} & Then & $\begin{array}{l}\text { after three } \\
\text { weeks }\end{array}$ & $\begin{array}{l}\text { my mother } \\
\text { and my } \\
\text { brother }\end{array}$ & came & to Honiara & & \multirow[t]{2}{*}{$\begin{array}{l}\text { Record of } \\
\text { Events }\end{array}$} \\
\hline & & Circ: Time & & Action & Circ: Place & & \\
\hline \multirow{2}{*}{8} & so & & [I] & $a m$ & very happy & & \multirow{4}{*}{ Comment } \\
\hline & & & & Relating & Attribute & & \\
\hline \multirow{2}{*}{9} & because & & my mother & was come & & & \\
\hline & & & & Action & & & \\
\hline
\end{tabular}




\begin{tabular}{|c|c|c|c|c|c|c|}
\hline \multirow[t]{2}{*}{10} & $\begin{array}{l}\text { after four } \\
\text { weeks }\end{array}$ & my mother & told & me & & \multirow{4}{*}{$\begin{array}{l}\text { Record of } \\
\text { Events }\end{array}$} \\
\hline & Circ: Time & & Saying & Participant & & \\
\hline \multirow{2}{*}{11} & & & $\begin{array}{l}\text { to [go] } \\
\text { shopping }\end{array}$ & $\begin{array}{l}\text { [for] some dresses } \\
\text { and skirts }\end{array}$ & for me & \\
\hline & & & Action & Circ: Reason & $\begin{array}{l}\text { Circ: } \\
\text { Reason }\end{array}$ & \\
\hline
\end{tabular}

Table 5: "Sera” (part analysis, clauses 1 - 11) (SISTA 1)

In terms of recount structure, Sera's text is strengthened through Comment stages worked throughout the text, providing reflection on the various events: she liked going to Kolale; she was very happy because my mother was come [came], and then sad when her mother left, I cry for her. In this regard, John's text is more similar to the weaker texts, using only two comments: I'm so interesting [interested] to watch the game; and, we enjoy eating pig and fish. On the whole, the texts in this stronger group use forms of appraisal throughout the text, realised through clauses such as I am so/very happy, I am very happy about our hunting trip to Papatura Island, I was very pleased with all the things we buy, I hope to have another Christmas holiday like this.

Since Sera had a rich experience to draw upon, there are a variety of process types, using material processes for actions (e.g. arrived, took, give, go shopping), and internal process to show pleasure (/ liked going), a relating process to provide an attribute (I am very happy) and processes for indicating talk (e.g. told, said). In fact, longer texts contained stretches of dialogue (e.g. So we say to him if you want to climb you just climb it and he says it's okay; My uncle told me about a celebration and he asked me did you want to go with me and I said yes) however, such runs of talk are not complex or linguistically detailed. Yet, dialogue does present the means of including particular interactions in the recount that weaker texts are not able to do, most notably the thoughts and actions of participants beyond the narrator.

John's text also contains some process types beyond material, particularly to verbal processes to include talk: welcome, told, call. Other stronger texts contain predominantly material processes, congruent with a recount, but also a variety of processes throughout, such as verbal (mainly, said), mental (I thought to myself, we enjoy my school holidays, I love you) and relational (our pot was full of fish, my team was the best, there are a lot of things, we have many stories).

Stronger texts tended to include various participants as actors, rather than solely I as seen in weaker texts. While a personal recount is concerned with the actions of the writer, Sera is also able to recount the actions of other people and things my cousin sister, my mother and my brother and later, the car, she, the ship. She also includes a range of people, places and things with in the text, though the noun groups are still very short, as seen in the earlier texts. Similarly, John shifts between participants, but without much description beyond my 
sister, his [her] husband, the fish, again, a feature of most texts where most noun groups are prefaced with my, some or the: my grandfather, my sister, my teacher, some firewood, some sweets, the celebration, the coconut, the wharf. A few writers create longer participants, such as the student enamoured of a larger sells-everything store on her trip to Honiara, $a$ beautiful shop called "Ausmart" where she bought all the things that we want. Such extended noun groups are rare in the sampled texts.

Most noticeable in these stronger texts is the control over circumstances, particularly being able to use time circumstances in Theme position to orient the events across the text. Like texts at all levels, Sera begins with a circumstance of time, In my holidays. However, she goes on to organise her events around time: after three weeks, after four weeks, on [the] morning and, later in a clause, tomorrow. John uses a similar pattern: last week, at my arriving, at the evening, the next day. Other students use one day, on Tuesday morning, the next day, after the holiday to unfold events.

Still looking at circumstances, the stronger texts use not only a greater number overall, but a greater variety of types. While place still predominates in these texts - down to the beach, to the village, near my village - and accompaniment is still common - with my mother, with my brother, with my father - like Sera, writers in this groups employ other types, such as reason (for fishing) and manner (suddenly, quickly).

However, it is this latter group of being able to say how things happened through circumstances of manner that are conspicuously absent across all texts. It would be expected that student writers provide detail as to how they went (for example, quickly, straight way or slowly), how they played football (for example, well or badly), how they danced (for example, excitedly, traditionally or happily). Yet this resource is under-used across the entire sample.

Overall, there is a paucity of circumstances across texts - strong and weak - with many clauses containing no detail to the activities. To illustrate this, across the sample there is an average of 15 clauses per text ( 25 clauses in stronger texts, 10 in weaker texts, for contrast), but only 10 clauses per text might contain a circumstance, even fewer considering the propensity for multiple circumstances in the orienting clause. Of circumstances used, over $56 \%$ denote place, $28 \%$ for time, leaving around $7 \%$ each for accompaniment and reason, and less than $2 \%$ for manner. In other words, saying how something happened rarely occurs at any level. This appears a gap in language resources and remediating it could improve how students think about and write about experiences.

To conclude the discussion of the stronger texts, a final aspect is what writers foregrounded in their clauses, that is, put in Theme position. Sera's text uses a variety of ways to focus the clause, including time, logical conjunctions, such as because, so, and various participants. John also moves the focus of the clause between time and participants. This movement of Themes choices breaks some of the repetitiveness seen in the weaker texts, though writers 
are still re-using phrases and words that are familiar, allowing them to bring focus to various aspects of the activity that they are recounting.

Finally, while differences between stronger and weaker texts are evident, they are not vast, indicating that there are a number of linguistic gaps that can be addressed in re-designing language materials. These are outlined in the next section.

\section{Taking action}

As noted from the outset, this analysis was firmly oriented around action, to provide data that could be used to review and improve the English textbooks at Years 4, 5 and 6 . This analysis pointed to several weakness in writing at these levels:

- Text structuring to include all possible phases

- Over-reliance on material processes

- Little detail included within noun groups

- Over-reliance on place and time as circumstantial detail

- Repetitive starting points for clauses/Theme choices

With these findings in mind, a text-based teaching and learning structure (Feez, 1998; Rothery, 1994) was used to re-draft textbooks. Model texts provide examples of languagein-use, and subsequent activities help to first understand text and language, and then build new texts. Lessons build language cumulatively across and between units, enabling students to continually recycle language towards constructing an extended text as the unit's final activity. A core consideration for these textbooks is that they provide explicit notes and explanations for teachers and students themselves, to understand how language works and how to use it.

Rather than outline examples from all facets of language, a selection of activities taken from the Year 4 textbook will be presented here to illustrate how the findings from the SISTA analysis directly influenced the choice of language activities in the new texts. Year 4 books were drafted in late 2017/2018 with Years 5 and 6 currently in development by an international consultancy team in coordination with the Ministry literacy staff. The activities shown here address the identified weakness in using circumstances, specifically, to extend the possible choices of time and place, and to explicitly show how to use manner in detailing events. While it does not use recounts as shown in the analysis, the choice here has been taken to illustrate the way language is supported, particularly in the early part of the program.

The fifth unit of the textbook, Animal Stories, is a 10-day program ${ }^{3}$ of lessons to strengthen narrative writing. This text type is enhanced by using a variety of circumstances, similar to

\footnotetext{
${ }^{3}$ As there are many national and community interruptions to the school week, it was thought better to base the lessons about days and encourage teachers to pick up with the next day in the program rather than trying
} 
the recount, and so is an appropriate place to introduce students to how to use this language resource. Prior to this unit, students looked at information reports and linguistic elements such as names and places for entities in a text (participants), structuring and extending noun groups, a range of prepositions, and how to structure descriptions.

To start the unit, a model narrative is presented, one with a range of circumstances of time in Theme position. An explicit explanation about how these are used to order events and examples from the text are given, as shown in Figure 2. The accompanying teachers' notes suggest that the students locate other examples in the text, which include the next morning, then, now. Thus, students focus on this language in use.

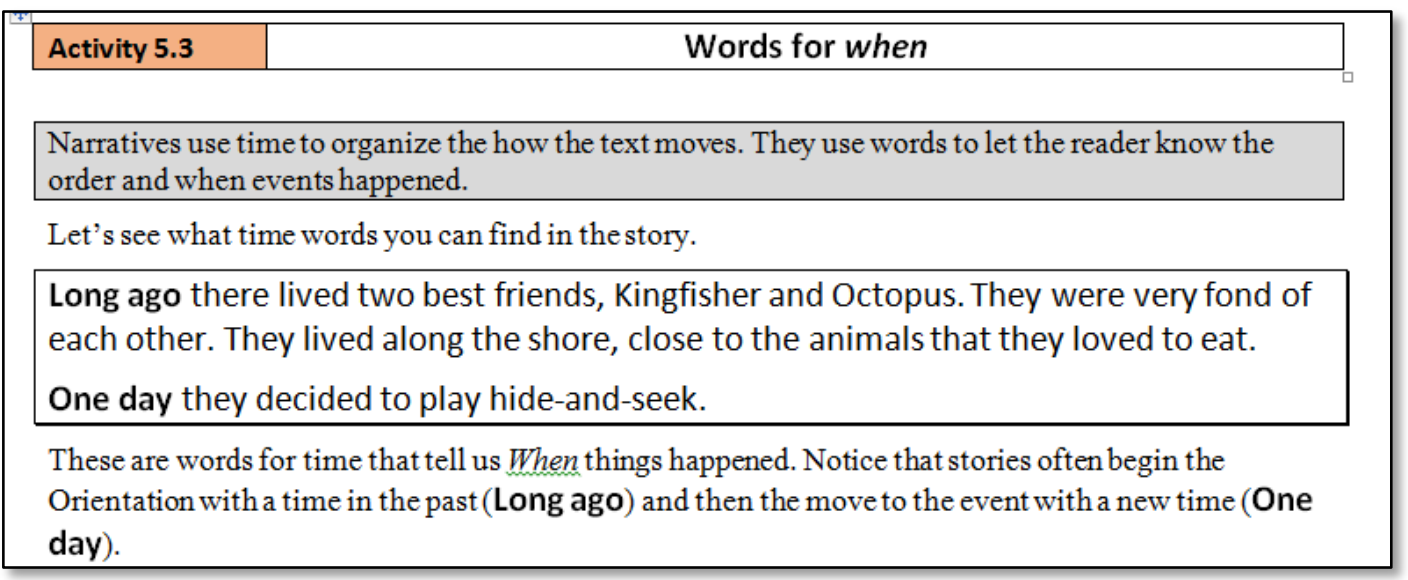

Figure 2: Introducing circumstances of time, from Year 4 textbook, draft

The repertoire of time circumstances is expanded with new examples, and an activity that provides an opportunity to choose and use these phrases, seen in Figure 3. Teachers' notes encourage accepting various ways to fill in the paragraph rather than insisting on one "correct" paragraph that all students copy. Teachers are also encouraged to check that choices maintain meaning, that the paragraph does not start with after that, for example.

\begin{tabular}{|c|c|c|c|}
\hline \multicolumn{4}{|c|}{ Here are some more words that we could use } \\
\hline once upon a time & the next day & yesterday & then \\
\hline a long time ago & one time & later & after that \\
\hline one morning & early & late & in the afternoon \\
\hline meanwhile & soon & eventually & today \\
\hline \multicolumn{4}{|c|}{ Try to use them in this small story } \\
\hline \multicolumn{4}{|c|}{$\begin{array}{l}\text { there were three little pigs. They lived with their parents. } \\
\text { the pigs decided to build their own houses. They built three houses, } \\
\text { but a big wolf came and wanted to eat the pigs. he came and tried to } \\
\text { break down the houses, but he couldn't break the stone house. } \\
\text { and went away without eating the pigs! those pigs are safe. }\end{array}$} \\
\hline
\end{tabular}

to cram extra "days" into the weekly program as teachers had felt pressured to do. The material was created for fewer days than on the school calendar. 
Figure 3: Expanding circumstances of time, from Year 4 textbook, draft

Some lessons later and with a new narrative, circumstances of place are linked to what students had learnt about previously (in Unit 3) about prepositions in order to show how they are used within a phrase, again, using the stimulus text as a model of language-in-use (see Figure 4). The question What groups of words tell me where? provides a prompt for students to identify circumstances in their reading and writing.

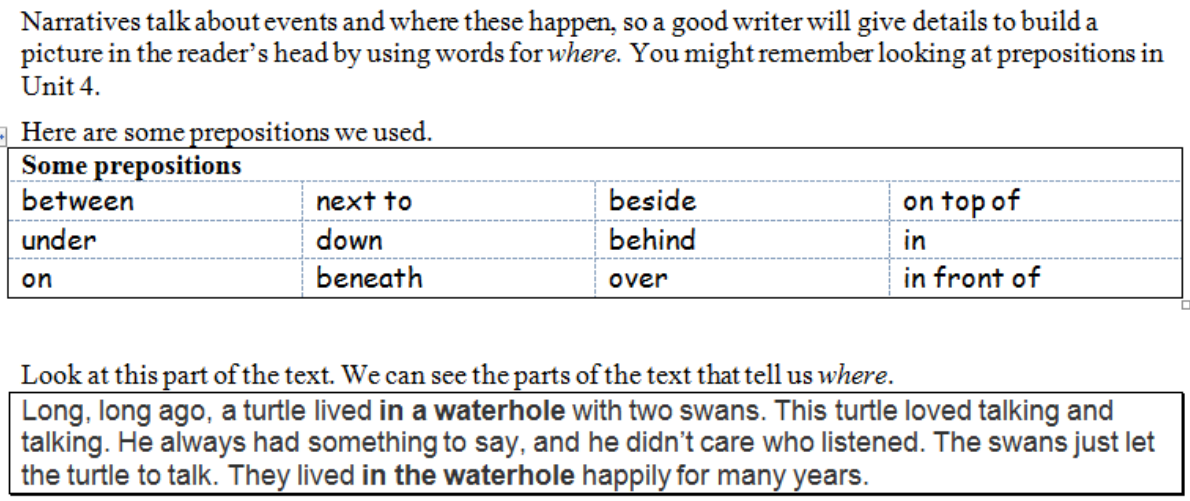

\begin{tabular}{|l|l|l|l|}
\hline between & next to & beside & on top of \\
\hline under & down & behind & in \\
\hline on & beneath & over & in front of \\
\hline
\end{tabular}

Look at this part of the text. We can see the parts of the text that tell us where.

Long, long ago, a turtle lived in a waterhole with two swans. This turtle loved talking and talking. He always had something to say, and he didn't care who listened. The swans just let the turtle to talk. They lived in the waterhole happily for many years.

Now you try. Remember to look for words that answer the question "What groups of word tell me where?"

Soon they passed over a small town. A few people looked up and saw the funny sight of the swans and the turtle.

Figure 4: Working with circumstances of place, from Year 4 textbook, draft

Of course, both circumstances of place and time are already present within students' test texts, thus, this established knowledge provides the starting point for making explicit what students may be doing tacitly. In moving to circumstances of manner - generally absent in writing where they would be appropriate to include - a similar strategy of observing language within a text and exploring how it is worked back into writing is used. For example, students are told explicitly that narratives are strengthen ed by using when, where and how, seen in Figure 5.

\section{Using How}

Narratives are about the activities and events of the characters. A very important feature of good writing is to tell not only what happened, but how it happened.

In a story we need to know when, where and how.

Figure 5: Introducing circumstances of manner, from Year 4 textbook, draft 
Parts of the model text are then explored using prompts similar to those used by Rose (2016) in his strategy of Detailed Reading, and which have already been included in the textbooks at Years 2 and 3 level. The questions starting How...? bring attention to the words that give the circumstance of manner, seen in Figure 6.

He was stretched out on the ground and snoring softly.

\begin{tabular}{|l|l|}
\hline Who is this about? & he \\
\hline What was he doing? & stretched out, snoring \\
\hline Where was he doing this? & on the ground \\
\hline How was he snoring? & softly \\
\hline
\end{tabular}

Figure 6: Identifying sentence elements, from Year 4 textbook, draft

Other sentences taken from the stimulus text for students to deconstruct were: He reached out with his huge paw and quickly grabbed Rat, and Lion opened his mouth, poked out his enormous tongue and slowly leaned in to eat Rat, containing circumstances of manner in various positions within the sentence.

To focus more specifically on using how actions are enacted, students are given a complete paragraph that they can elaborate with manner using prompts: How was she walking? How was she thinking? How would she study?, shown in Figure 7. Such prompts mimic the questions student could then ask themselves as they write, a means of bringing to attention this linguistic resource.

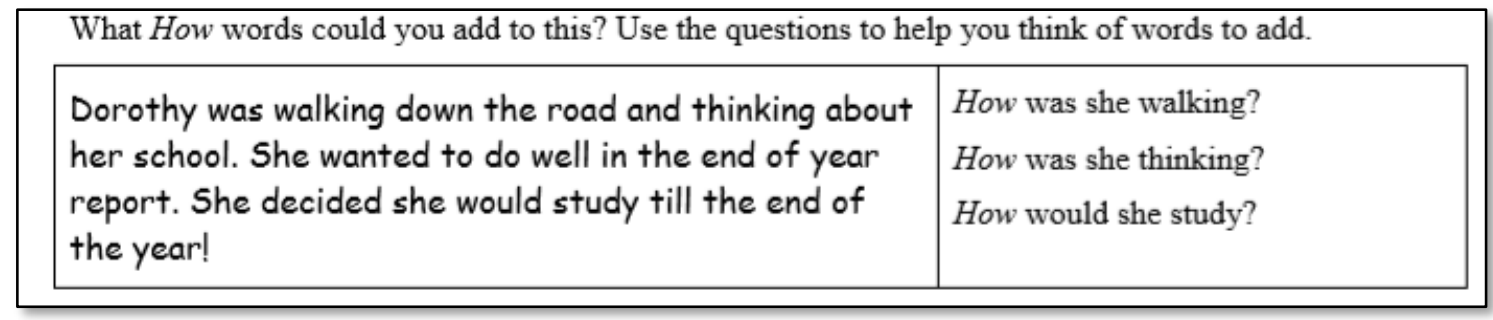

Figure 7: Exercise to add manner to writing, from Year 4 textbook, draft

Further attention to circumstances is included in the subsequent unit that looks at reading and writing explanations - when, where and how assist to detail phenomena - and again in Unit 7, where circumstances of reason are introduced to provide cause and effect in explanations. Thus, while language is introduced within a particular genre, it is further expanded and possibilities explored within other appropriate genres. More complex structures can then be built at Years 5 and 6 .

\section{Implications and conclusion}


This paper sought to illustrates how large-scale testing can provide data to orient decisions in literacy reform, through identifying weaknesses that new strategies and materials can explicitly address. In this case, linguistically-focused analysis of SISTA scripts provided particular information about knowledge and gaps in students' writing, beyond merely the statistics and patterns of performance.

The framework of SFL offers a meaning-oriented, multi-level framework, moving away from the surface features of texts that appeared to take the attention of markers, to understand macro and micro features of students' writing. The same framework then provides the basis for language teaching, using the same understanding of the strata of language to move within in looking at texts and exploring the choices language provides.

While the original textbooks contained rich stimulus texts, the pedagogy did not capitalise on the language potential, being stuck in episodic instances of language use. Using a teaching and learning cycle developed by SFL practitioners based on explicit and visible pedagogy - applied to those areas that Solomon Island children appear to have difficulty in establishing - greater use can be made of the texts, to bring attention to how language choices are made to make meanings. Re-working current texts and expanding with new rich texts provides a greater range of resources to build the field for students' writing.

Importantly for teachers' professional development and knowledge-building, the new textbooks aim to explicit explanation at each step of text deconstruction, exploration and re-construction, helping teachers to see and understand how texts and language works. Macken-Horarik et al. (2011) propose the idea of "good enough grammatics", providing enough specific and specialised knowledge that teachers will be able to support students' language development and make a difference to student achievement. Time will tell if the level of support designed into the textbooks has helped Solomon Island teachers to learn about language and how to teach language effectively.

Beyond merely providing sound pedagogy and knowledge about language remains the larger issue of the socioeconomic differences among writers in various Solomon Island settings. Having access to experiences that are valued by markers will continue to be a point of inequality if testing privileges those with particular resources and opportunities. Such issues will need greater attention to ensure high stakes testing and decision-making is able to account for all experiences of students and teachers across the archipelago.

Finally, in observing marker behaviour in the SISTA 2015 testing, building more knowledge about language would benefit not only classroom teachers, but also those who mark school tests at a national level. While SISTA is a sampled snapshot of achievement, the end of year national testing of Year 6 students is a high stakes activity, deciding which students will progress to high school and with what choices of school. Building knowledge about language with assist markers to make more reliable decisions and provide fairness of opportunity.

Of course, several limitations to this planned reform activity exist. The books, planned and outlines drafted in 2016, remain incomplete, due to staff turnover, funding and identifying 
suitable staff and timing for the task within an education with many competing needs. Thus, teachers and students continue to use the older, less focused texts. The results from SISTA 2017 and 2019 have not been made publicly available, but there is no reason to imagine much change in results, save for the strengthened focus on English language use in Years $1-$ 3 , where training involved school principals who is typically the Year 6 teacher, thus some residual learning might be expected. Greater focus on literacy generally has come through the new donor-funded Leaders and Education Authorities [LEAP] project which may also have been responsible for the slight rise in literacy achievement measured by the regional PILNA testing in 2018, seeing 54\% of Year 4 students achieve the Pacific literacy standard up from $50 \%$ in 2015 - and $70 \%$ of Year 6 students reaching the standard, up from $67 \%$ (MEHRD, 2019). Despite this rise, the results point to a need to build more classroom focus on learning about language.

In conclusion, while test papers are considered a valuable "snapshot" of student achievement, with principled analysis they also provide valuable data for identifying what students can currently do and the gaps that point to avenues for improvement. Using such data can assist governments and donors to direct resources toward strategic and focused classroom activity, strengthening the ability of teachers to make the difference in the achievement of students, to learn language necessary for success in the school context.

Acknowledgements: Thanks to Dr Franco Rodie, the Permanent Secretary of MEHRD, for permission to analyse and publish from this data. Thank you, also, for valuable advice from colleagues Jenny Hammond and Trish Weekes in the preparation of the paper, as well as the advice of anonymous reviewers: any errors are my own. 


\section{References}

Australian Centre for Educational Research [ACER]. (2021a). PIRLS - Progress in International Reading Literacy Study https://www.acer.org/au/pirls

Australian Centre for Educational Research [ACER]. (2021b). PISA https://www.acer.org/au/pisa

Australian Council for Educational Research [ACER]. (2016). Solomon Islands Standardised Tests of Achievement -SISTA, English and Mathematics, Year 4 and Year 6, Report 1- Main study 2015. ACER.

Australian Council for Educational Research [ACER]. (2013). Solomon Islands Standardised Tests of Achievement - SISTA, English and Mathematics, Year 4 and Year 6, Report 1- Main study 2013. ACER.

Australian Curriculum Assessment \& Reporting Authority [ACARA]. (2016). National Assessment Program. https://www.nap.edu.au/home

Arber, S. (1993). The research process. In Gilbert, N. (Ed.) Researching social life (pp. 32 - 50). Sage.

Butt, D., Fahev, R., Feez, S., Spinks, S. \& Yallop, C. (2000). Using functional grammar: An explorer's guide. National Centre for English Language Teaching and Research.

Christie, F. (2002). Classroom Discourse Analysis: a functional perspective. Continuum.

Christie, F. (2013). Genres and genre theory: A response to Michael Rosen. Changing English, 20(1), 11-22.

Cincotta-Segi, A. (2011). Signalling L2 centrality, maintaining L1 dominance: Teacher language choice in an ethnic minority primary classroom in Lao PDR. Language and Education 25(1), 19-31.

Coffin, C. (2010). Language support in EAL contexts. Why systemic functional linguistics? NALDIC Quarterly, Special issue, 2-5.

Commeyras, M. (2007). Scripted reading instruction? What's a teacher educator to do? Phi Delta Kappan, 88(5), 404-407.

Darling-Hammond, L. (2004). Standards, accountability, and school reform. Teachers College Record, 106(6), 1047-1085.

Derewianka, B. \& Jones, P. (2010). From traditional grammar to functional grammar: bridging the divide. NALDIC Quarterly, 8(1), 6-17.

Derewianka, B. \& Jones, P. (2016). Teaching language in context, 2nd. Oxford University Press.

Dreher, K. (2012). Tests, testing times and literacy teaching. The Australian Journal of Language and Literacy, 35(3), 334-352.

Dresser, R. (2012). The impact of scripted literacy instruction on teachers and students. Issues in Teacher Education, 21(1), 71-87.

Education Quality and Assessment Program [EQAP]. (2019). Pacific Islands Literacy and Numeracy Assessment 2018 Regional Report. Pacific Community/Communauté du Pacifique https://reliefweb.int/sites/reliefweb.int/files/resources/PILNA-Regional-Report-2018.pdf

Eggins, S. 1994. An Introduction to Systemic Functional Linguistics. London: Pinter Publisher.

Feez, S. (1998). Text-based Syllabus Design. National Centre for English Language Teaching and Research, Macquarie University.

Firkins, A., Forey, G., \& Sengupta, S. (2007). Teaching writing to low proficiency EFL students. ELT Journal, 61(4), 341-352.

Gebhard, M., Chen, I. A., \& Britton, L. (2014). "Miss, nominalization is a nominalization:" English language learners' use of SFL metalanguage and their literacy practices. Linguistics and Education, 26, 106-125.

Glewwe, P. W., Hanushek, E. A., Humpage, S. D., \& Ravina, R. (2011). School resources and educational outcomes in developing countries. National Bureau of Economic Research.

Goodman, K. S. (1977). Acquiring literacy is natural: Who skilled Cock Robin? Theory into practice, 16(5), 309-314.

Graves, D. H. (1983). Writing: Teachers and children at work. Heinemann Educational Books. 
Guerrero, G., Leon, J., Zapata, M., Sugimaru, C., \& Cueto, S. (2012). What works to improve teacher attendance in developing countries? EPPI Centre, University of London.

Halliday, M. A. K. (1968). Notes on transitivity and theme in English: Part 3. Journal of linguistics, 4(2), 179-215.

Halliday, M. A. K. (1973). Explorations in the functions of language. Edward Arnold.

Halliday, M. A. K. (1975). Learning How to Mean: Explorations in the Development of Language. Edward Arnold.

Halliday, M. A. K. (1992): "How Do You Mean”. In Halliday, M.A.K. (2002) On Grammar. Collected Works of M. A. K. Halliday, Volume 1 (pp. 352-368). Continuum.

Halliday, M. A. K., \& Matthiessen, C. M. (2013). Halliday's introduction to functional grammar. Routledge.

Harwood, N. (2013). Content, consumption and production: Three levels of textbook research. In Harwood, N. (Ed.). English language teaching textbooks: Content, consumption, production (pp. 1 -44). Springer.

Jones, R., \& Lock, G. (2010). Functional grammar in the ESL classroom: Noticing, exploring and practicing. Springer.

Krashen, S. (1985). The Input Hypothesis: Issues and Implications. Longman.

Lavrakas, P. (Ed.). (2008). Encyclopedia of Survey Research Methods. SAGE Publications, Inc.

Lin, A. M. (2016). Language across the curriculum \& CLIL in English as an additional language (EAL) contexts. Springer.

Love, K. (2010). Literacy pedagogical content knowledge in the secondary curriculum. Pedagogies: An International Journal, 5(4), 338-355.

Macken-Horarik, M. (1998). Exploring the requirements of critical school literacy: a view from two classrooms. In F. Christie, \& R. Misson (Eds.). Literacy and Schooling. (pp. 84-113). Routledge.

Macken-Horarik, M., Love, K. \& Unsworth, L. (2011). A grammatics 'good enough' for school English in the 21st century: Four challenges in realising the potential. Australian Journal of Language and Literacy 34(1), 9-21.

Macken-Horarik, M., \& Morgan, W. (2011). Towards a metalanguage adequate to linguistic achievement in post-structuralism and English: Reflections on voicing in the writing of secondary students. Linguistics and Education, 22(2), 133-149.

Macqueen, S., Knoch, U., Wigglesworth, G., Nordlinger, R., Singer, R., McNamara, T., \& Brickle, R. (2019). The impact of national standardized literacy and numeracy testing on children and teaching staff in remote Australian Indigenous communities. Language Testing, 36(2), 265287.

Martin, J. R. (2009). Genre and language learning. Linguistics and Education, 20(1), 10-21.

Martin, J. R. \& Rose, D. (2005). Designing literacy pedagogy. In J. Webster, C. Matthiessen \& R. Hasan (Eds.) Continuing discourse on language (pp. 251-280). Continuum.

Martin, J. R., \& Rose, D. (2008). Genre Relations-Mapping Culture. Equinox eBooks Publishing.

Martin, J. R., \& White, P. R. R. (2005). The language of evaluation: appraisal in English. Palgrave Macmillan.

Matthiessen C.M.I.M. (1995). Lexicogrammatical cartography: English systems. International Language Sciences Publishers.

Matthiessen C.M.I.M. \& Halliday M.A.K. (2009). Systemic functional grammar: a first step into the theory. Higher Education Press.

Ministry of Education and Human Resource Development [MEHRD]. (1995). Nguzu Nguzu English Standard 1, Teachers' Guide, Ministry of Education and Human Resource Development.

Ministry of Education and Human Resource Development [MEHRD]. (2005a). Nguzu Nguzu English Standard 5, Teachers' Guide 1, Ministry of Education and Human Resource Development.

Ministry of Education and Human Resource Development [MEHRD]. (2005b). Nguzu Nguzu English Standard 5, Pupil's Book 2, Ministry of Education and Human Resource Development. 
Ministry of Education and Human Resource Development [MEHRD]. (2019). Pacific islands literacy and numeracy assessment (PILNA) assessment results (Briefing). Available www.mehrd.gov.sb

National Association for Language Development in the Curriculum [NALDIC]. (2010). NALDIC Quarterly, Special Issue.

Probyn, M. (2006). Language and learning science in South Africa. Language and Education, 20(5), 391-414.

Quinn, M. (2004). Talking with Jess: Looking at how metalanguage assisted explanation writing in the middle years. Australian Journal of Language and Literacy, 27(3), 245-261.

Quinn, Marie. (2013). Talking to learn in Timorese classrooms, Language, Culture and Curriculum, 26(1), 179-196.

Quinn, M. (2021). SFL in Solomon Islands: A Framework for Improving Literacy Practices in Primary School. Íkala, 26(1), 207-223.

Rose, D. (2016). Engaging and supporting all our students to read and learn from reading. PETAA.

Rothery, J. (1994). Exploring Literacy in School English Write it Right Resources for Literacy and Learning. Metropolitan East Disadvantaged Schools Program.

Schneider, R. M., \& Krajcik, J. (2002). Supporting science teacher learning. Journal of Science Teacher Education, 13(3), 221-245.

Schleppegrell, M. J. (2016). Content-based language teaching with functional grammar in the elementary school. Language Teaching, 49(1), 116 - 128.

Silverman, D. (2001). Interpreting qualitative data: methods for analysing talk, text and interaction $\left(2^{\text {nd }}\right.$ ed.). Sage Publications.

Simons, G. \& Fennig, C. (Eds.) (2017). Ethnologue: Languages of the World (20 ${ }^{\text {th }}$ ed.). SIL International.

Solomon Islands Government. (2016). Education Act. Solomon Islands Government.

Solomon Islands National Statistics Office [SISNO]. (2015). Solomon Islands Demographic and Health Survey. SISNO.

Swain, M. (1985). Communicative Competence: Some Roles of Comprehensible Input and Comprehensible Output in its Development. In S. Gass \& C. Madden (Eds.), Input in Second Language Acquisition. Newbury House.

World Bank. (2018). World development report 2018. World Bank. 
Appendix 1: "John" (partial analysis, clauses 1-11)

Last week I made my holiday to my sister's house in Auki town. at my arriving my sister welcome me and happy to saw me. At the evening he cooked the fish and he asked me. Tomorro you will go with me to the tournament happen at Alegegeo and I say yes to her. The next day his husbane told us to went on his car. When we arrived at Alegogeo I saw my brother played with some boys he school with then. I'm so intresting to wast the game but my sister call my name came on we went back now. When we arrived at my sisters house we enjoyed eat pig and fish. on the next day I went back to my home at west tawaio.

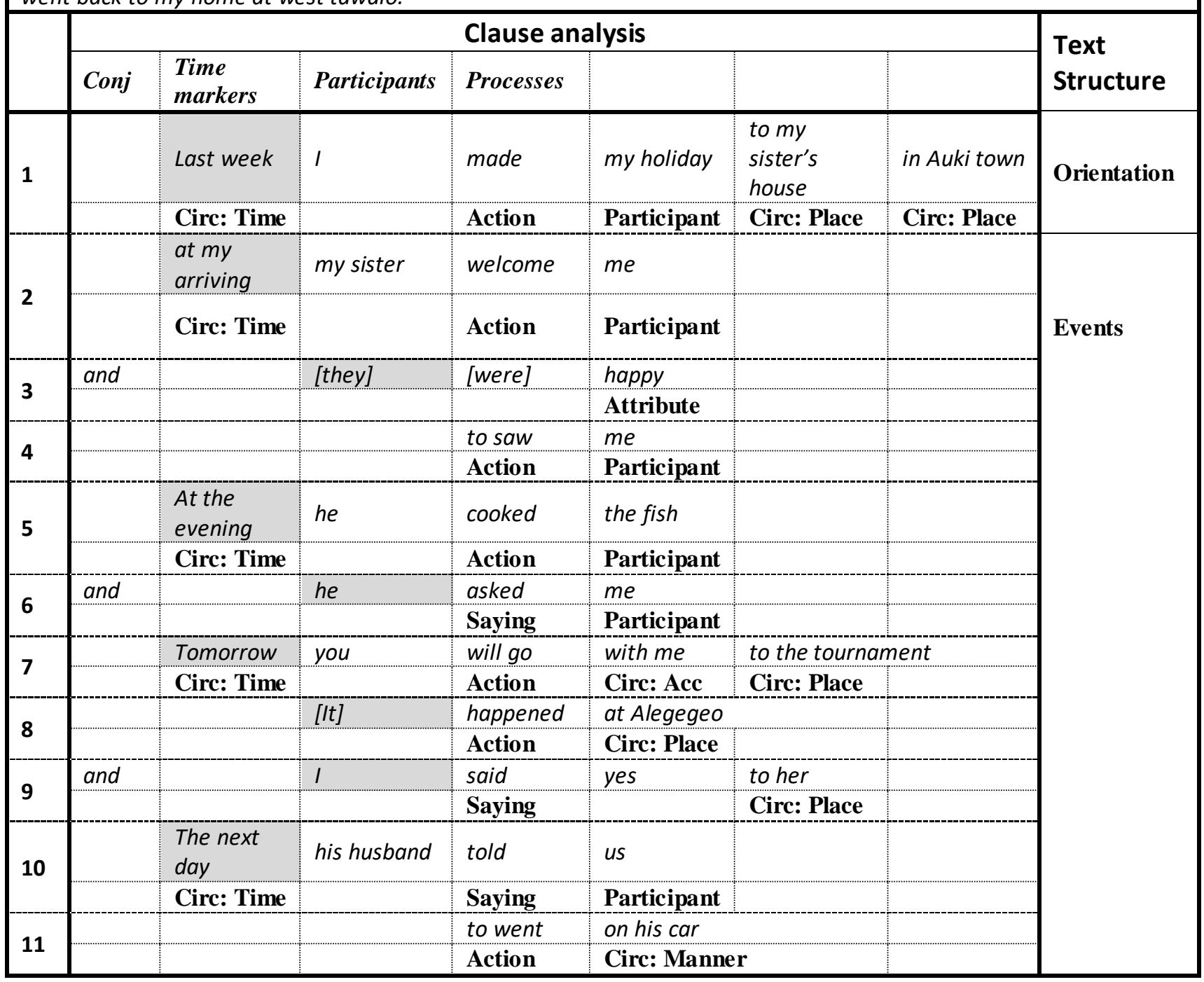

